\title{
People's Cognitive Beliefs and Definitions About Homosexuality
}

\author{
PhD (C.) Desarta Spahiu \\ Vice President of Technical Economic School, Albania
}

doi: 10.19044/esj.2017.v13n8p75 URL:http://dx.doi.org/10.19044/esj.2017.v13n8p75

\begin{abstract}
This study aims to explore and analyze the process of defining homosexuality as an act of political implications. Defining the homosexuality influence the terms of social and political debate and implies distinct lines of actions. Qualitative analysis of the individual interviews used in this study shows how people discursively construct opinions about homosexuality. This study includes 10 participants using in-depth interviews and literature review as a research method. Evidence of this study indicates that cognitive beliefs and definitions about homosexuality are related directly and indirectly on attributions of causes that are biological or lifestyle choices in discourses. Surprisingly there is a significant number of responses about homosexuality that are not clearly defined. For some people, homosexuality can purport multiple things and others don't think that they have the knowledge to give an opinion about the reasons that causes the homosexuality. In order to generate statistical estimates about how prevalent these different patterns of discourse are in the population in large, we must generate survey instruments that are more capable of measuring the complexity of people's understandings of homosexuality.
\end{abstract}

Keywords: Cognitive beliefs, definitions, LGBTI, gays and lesbians, homosexuality

\section{Introduction}

The word homosexuality was created by a German psychologist in the late $19^{\text {th }}$ century, Karoly Maria Benkert. Even though the word is new, the debate about sexuality and same-sex relationships, particularly, have occasioned thoughtful discussions all over the world (Lau, 2004). In view of the fact that the history of understandings of homosexuality is significant to the philosophical issues raised by those understandings, it is essential to refer to the natural law that still takes an important role in present-day debates about homosexuality in religion, people beliefs and attitudes and also 
politics. Possibly the most important current social change about homosexuality is the materialization of the fact that meanings of gender, homosexuality, marriage and family have shifted. A central question raised in public opinion is whether homosexuality is socially constructed or simply driven by genetic forces. The debates about homosexuality, partly because they often engage public policy and lawful issues, have a tendency to be polarized.

Defining homosexuality is an act of political importance (Stein, 1990). Whether a someone defines homosexuality as a mental disease, a choice, an occurrence caused by natural causes, or an occurrence caused by social education, has consequences for whether people of LGBTI community are defined as patients, deviants, a minority group, or victims of circumstance (Johnson, 2004). Because Albanians recognize that homosexuality has traditionally been treated as harmful by the majority of society, each definition implies a line of action: patients need to be cured, deviants should be educated, the minorities are supposed to be established equal rights, or the less privileged need to be tolerated. Therefore, defining homosexuality is related with propelling of political indications (Cherlin, 2004; Powell, 2010). Maybe it is for this motive that the attribution of homosexuality has recognized so much interest among scholars and media.

Defining homosexuality influence the terms of political debate and the merits of distinct lines of actions (Carter, 2004). For illustration, if someone is born gay or lesbian, like in the case of ethnic minorities, it should be provided equal rights and discrimination against him should be banned. Contrary to this, if someone simply chooses to be gay or lesbian, then like alcoholics or gamblers, their actions choices needs to be corrected or dispirited rather than secluded by "particular" rights and civil liberties. For individuals that are politically prompted, liberals achieve an advantage in the first case, at the same time as conservatives achieve an advantage in the subsequent. It is as a result expected that public view studies notice that people's definitions of homosexuality are related with opinions about samesex marriage.

\section{Methodology}

The research method used to study cognitive beliefs about homosexuality is related to a qualitative type of research. I have conducted a qualitative analysis in order to provide deeper insight into the people definition of homosexuality. The data were collected through semistructured, qualitative individual interviews with 10 participants from different cities of Albania, who had various demographic characteristics. Site selection and recruitment of my sample were guided my assessment of the requirements for addressing the theoretical agenda. The qualitative interview 
analysis is important because it provides an understanding of the patterns of support and opposition and what homosexuality means to people in the social and cultural environment in which they reside. The approach to this qualitative interviewing is a communication-theoretic variant of a theoretical logic based on Rubin and Rubin (2005) that is "interpretive constructionist", meaning that the participant's opinions and answers to questions are not automatically objective facts that the researcher assumes are true but they should be considered as the interviewee's version or perception of reality, which is created by the person's social setting, cultural repertoire, and interactional background.

\section{Results}

In interviews that I have conducted, I found that the process of defining homosexuality is more multifaceted and a complicated task for participants than we would have otherwise expected. Beside of the simple assessment that homosexuality is a sexual attraction involving people of the same sex, many participants had some difficulty levels expressing what they assume homosexuality is as well as what causes it. Despite the fact that some people gave a single, unambiguous answer, many people did not identify the causes and many others considerate that there were numerous causes or that the definition relies on the person.

Some people gave very straightforward answers to what they thought causes homosexuality and their answers were directly related to their views on same-sex marriage. For example, (A.), a 21- year old college student, brought up the topic of same-sex marriage sooner than I did, and then I asked her about it:

$R:$ I think it's fine and I think gay marriage should be accepted.

Q: Yeah?

R: Mmmm. (affirmative)

Q: Why do you think so?

$R$ : I don't think to be gay is an option to choose. It's just the way the brain is in certain people, and why shouldn't they get the same benefits as anyone else? (A., age 21)

In this case, (A.) used her definition of homosexuality as a reason for supporting same-sex marriage in a way that is suitable with her liberal opinionated views. Opponents of same-sex marriage also used uncomplicated definitions of homosexuality to rationalize their views. For example (G.), a 38-year old nurse, described her opinions about homosexuality this manner:

I believe that homosexuality is a way of life that someone choose but not that you are born to. I imagine that you can make a choice whether you want to live with someone of the same sex or whether you want to make an 
effort and make a marriage. I believe a lot of us can set out one way or the other and I think it's the choices we make, not what we're born to. (G, age 38)

(G.) had heard opinions from people that she knows who are gay and she do not agree that they were just born that way. She sees no explanation why someone who identifies as gay could choose to marry someone of the opposite sex. Consequently, she doesn't sustain gay marriage cause because gays and lesbians can already get married to someone of the opposite sex. It is worth pointing out that (G.) implicit indication to bisexuality in the passage above - "I think a lot of us can go one way or the other" - was sporadically invoked as indication that being gay or lesbian is all about how someone choose to live. When she was asked particularly about bisexuality and why someone would identify himself that way, she said:

I imagine that their experiences maybe have predisposed them one way or the other and I believe that's what makes the distinction. Just like all of us can make choices in our profession and in our marriage and whatsoever, you can also make a selection in what kind of lifestyle you choose. You don't have to choose something just for the reason that you have feelings in that way. (G., age 47)

Here, (G.) uses analogies to careers and marriages to give explanations on how people frequently have mixed feelings or could go either way in relationships, and that what matters is the choice that someone make.

Of course, a belief in bisexuality could also lend itself to tolerance as (A.), a 25 year-old student put it. If everyone were essentially bisexual, it could eliminate the stigma of homosexuality. Yet, the belief could just as simply increase disagreement to homosexuality for the reason that there would be a greater supposed threat of engaging in what some people consider as morally wrong sexual behavior. Simple or complex understandings of sexuality do not allow themselves easily to a single political line of action; one could represent either liberal or conservative ideas from complex definitions of homosexuality.

In my interviews, complex definitions of homosexuality were frequent. Most participants did not have clear, simple opinions about homosexuality that could be ideologically drawn in liberal or conservative viewpoints. Some of them thought of homosexuality in a single individual as being multi-causal, while others thought that there are different causes of homosexuality for different people. For those who thought homosexuality is multi-causal, it is worth pointing out that there is no reason taken for granted about why homosexuality could not at the same time have genetic, social, and behavioral components. Different participants advanced different 
combinations of the three definitions of homosexuality: nature, nurture, and behavior.

(D.) defined homosexuality as being caused by a combination of biological and environmental factors, but he denied that people chose to be gay:

R: I think it's not a choice. I would never say that a person wakes up one morning and says ' $I$ want to be a part of a despised minority in this country. I think that people don't have a choice in who they are attracted to. I think it's something that was raised. I think it's a biological thing and it's an environmental thing. That nature versus nurture argument.

Q: You think it's both?

$R$ : I think it's a combination of both. (D., age 27)

Although it takes (D.) a while to formulate a clear opinion about what causes homosexuality, he eventually settles on an argument that both biological and social-environmental factors cause homosexuality. He brackets the question of behavioral choice, whether or not someone chooses to act on their feelings, as being something different. For him, being gay is a sexual orientation rather than a behavior. By contrast, people who believe that homosexuality is a behavioral, lifestyle choice must confront the question of why certain people choose that lifestyle while others do not. Here, a multi-causal attribution of homosexuality includes behavioral factors, in addition to biological or environmental factors. For example (S.), considered the possibility that people might be born gay, but he ultimately thought that it was a combination of behavioral choice and social upbringing that made people identify as gay:

I think the majority of gay men are like that because is a choice. And I've heard a lot of stories where gay men are just gay because they hate their dad or they have daddy issues. Mommy issues. Something happened to them as a kid that affected them and now they're gay. And not to demean them or undermine them, but I just, that's kind of how I see it. Or maybe I'm wrong. I could be totally wrong. (S., age 28)

(S.) drew from stories about people he knew in order to support his opinion that people who identify as gay choose to be gay because of bad experiences that they have had as a child or because of the influence of their peers. However, he also freely admits that he doesn't know if he's right. He offered this opinion without feeling entirely confident in it.

Some informants thought that the reason that a person identifies as gay varies from person to person. From this point of view, some people may be homosexual because they are born that way, while others may be homosexual because of environmental factors, and still others choose to engage in homosexual activity in order to be rebellious. For example (M.), had such a view. His support for same-sex marriage and complexity of his 
views on homosexuality stood in stark contrast to my expectations, given his religious background and love of sports like football:

I think everyone should have the same rights, whether they're biologically, genetically gay or if they just are psychologically gay. That doesn't really make much of a difference. The only thing I think a guy or a gal should not be gay, like the only reason would be to get attention, which unfortunately I believe does happen. (M., age 19)

Later in the interview, I asked (M.) to say more about what he thinks cause people to be gay:

$R$ : Now there is probably sub-categories of like psychologically gay, you know, in their mind they're gay, so they are gay. There probably are some cases where there is a gene that just sets them off for the same sex....

Q: So do you think people are gay for different reasons? Would that be an appropriate way to interpret what you're saying?

$R$ : Different causes. The result is all the same. There isn't this type of gay person and, versus this type of gay person. They're all gay, but the initial cause of it... (M., age 19)

(M.) views about the attribution of homosexuality are not easy to classify, but he describes three different potential causes of homosexuality. His only negative evaluation of homosexuality is reserved for people who do it to just to get attention. Several participants that I interviewed, observed that women in particular occasionally engage in homosexual activity in order to get attention from men because men are likely to find female but not male homosexual activity erotic. Lastly, it is clear that many of the participants simply did not know what caused homosexuality and were attempting to formulate answers in response to my questions. Some people did not know simply because they didn't want to think about it. Some participants se uncomfortable answering my questions, and it seemed as though they would rather not think too much about homosexual activity. For example (L.), a 38 year-old religious devotee, struggled to articulate an answer to my question about the definition of homosexuality:

Q: What do you think homosexuality is? Like, if you were going to try to define it?

R: (Pause) I, I, I don't know. I just don't understand how someone could be, have those feelings and do those things with the same gender. I just (laughs), you could have a relationship with the same gender, friendship or whatever; why does it have to go to that next level? I just, I don't get that. (L, age 52)

Other people did not offer clear definitions of homosexuality because they did not think they knew enough to offer an answer. They did not feel as though they had enough factual knowledge about what the scientific studies 
were showing. (R.), a 51-year old liberal did not feel comfortable saying what he thought homosexuality was because of lack of information. However, as a result of my continued questioning, he seemed willing to try to formulate an opinion:

Q: Do you think people choose to be gay? Do you think homosexuality is a choice?

$R$ : That one I've thought about, and that one, I can't, I can't really answer because I don't have enough information on that. Choosing...in some way it could be, and some ways it can't. I just, I can't answer that. Q: Okay. Do you think homosexuality is influenced by, do you think people are sort of born that way, or do you think people are, it has to do with the way you were raised, or, do you have any thoughts about that? $R$ : I think some of it might be influenceD. The way that they see something, that they might be attracted to, or something. (R., age 51)

After an initial refusal to say whether or not he thought a person chose to be gay, (R.) attempted to formulate an answer to my follow-up question. However, the lack of substance in his answer might indicate that I was giving him a question that was too demanding. For informants, like (R.), who did not have strong opinions about the causes of homosexuality, the power of suggestion of my questions is evident. Sometimes the mere mention of one possible cause of homosexuality would lead an informant to agree. It would be a mistake to think that this person holds this opinion; rather, I argue that many people do not feel qualified to offer an opinion about what causes homosexuality and are thus willing to agree with the suggestion of an interviewer.

\section{Discussion}

At an ideological level, there are a large number of possible combinations of elements in people's belief systems, which leads to a variety of discursive positions. There is thus no innate predisposition toward incompatible conflict regarding this subject. In a conversational interview context, people's discourse about homosexuality attains a significant level of complexity and appears in many shades.

Thus, the people most likely to use libertarian discourses to talk about homosexuality are young participants with relatively tolerant attitudes about marriage and sexuality. Similarly, the most common ideologically conflicted discourse in my sample comes from older adults with religion backgrounds.

In describing this variation in people's cognitive beliefs, my goal has not been to make a claim about the quantitative or qualitative importance of any of these patterns of talk; rather, I have merely attempted to show that, to understand the controversy surrounding homosexuality, we should refuse the supposition of coherent worldviews and the straightforward classification of 
opinions as supportive and opposing. We must understand the full variation in the ways that people draw from different beliefs and also attitudes, values, life experiences in order to talk about homosexuality. Support for homosexuality appears to be both ideologically and sociologically related to positive attitudes toward gays and lesbians, the belief that homosexuality is not immoral, and the belief that homosexuality is an innate orientation. These beliefs are more likely to be held by people who are young, welleducated, who live in large cities, and who know gays and lesbians personally. By contrast, opposition to homosexuality appears to be related to negative attitudes toward gays and lesbians, the belief that homosexuality is a sin, and the belief that homosexuality is a lifestyle choice. These beliefs are more likely to be held by people who are older, more religious, who live in small towns and rural areas, and who do not know gays and lesbians personally.

Among demographic variables, I have paid particular attention to participant age-related differences, which I have expected to influence discourses about homosexuality primarily through people's attitudes and beliefs about homosexuality. Based on the expectations of age-related effects, people's discourses about homosexuality should reflect the dominant cultural constructions of homosexuality that existed when individuals came of age, such that younger people are more likely to articulate positive, supportive attitudes about homosexuality while older people are more predisposed to articulate oppositional views about homosexuality. This study confirms that supportive and oppositional discourses about homosexuality do appear to fall along the demographic and attitudinal contours, but also shows that there is enormous cultural complexity innate in people's discussions about homosexuality and that there is a mixture of discourses that are not easily classified as supportive or oppositional. Contrary to the expectations created by the quantitative analysis, people's beliefs about homosexuality often fail to fit together with one another, and they interrelate with agerelated differences and religious ideologies in a multiplicity of ways.

Similarly, the question of people's moral values regarding homosexuality is multi-dimensional, such that even people who believe that homosexuality is immoral do not necessarily believe that their personal moral values constitute an acceptable reason to have negative attitudes. An additional level of discursive complexity occurs when people's age-related differences cross-cut their religious ideologies, successfully pulling them at the same time in opposed directions. As a consequence of this complexity, many participants articulate opinions about homosexuality using a variety of middle-ground discourses. On the basis of this evidence, I argue that a substantial proportion of people have moderate, mixed beliefs and that polarization is likely to occur primarily in the context of political 
mobilization or survey measurement, where demands are placed on individuals to choose sides.

In sum, this study demonstrates that, even with our analytic attention restricted to the subject of homosexuality, there is such a degree of complexity in people's understandings of homosexuality that cognitive beliefs and definitions about homosexuality cannot be understood in simple terms of support and opposition. The use of middle ground discourses by participants suggests that they do not automatically have coherent worldviews regarding homosexuality and that people find ways to indirectly manage the apparent tensions and contradictions within their belief systems when talking about the topic. That these tensions and contradictions appear to be rooted in age-related differences and religious ideologies is significant.

In this study, I have first described how people's discourses about homosexuality largely revolve around the issue of what causes the homosexuality more generally. Second, I have described how people's understandings of homosexuality are composed of different cognitive beliefs and life experiences about homosexuality, and I have analyzed how they are used to talk about the issue. Finally, I have analyzed unambiguously supportive and oppositional opinions regarding homosexuality to show how these discourses are rooted in different cognitive beliefs and definitions about homosexuality.

\section{Conclusion}

Due caution should be taken when interpreting interview questions on the cognitive beliefs about homosexuality. The data of this study point out that cognitive beliefs and definitions about homosexuality are related on attributions of causes that are biological or lifestyle choices in discourses. Because of the variety of different ways in which people responded to questions about their definitions of homosexuality, I argue that people's cognitive beliefs about homosexuality are less clearly defined than politically-interested parties or survey researchers would like them to be. Forcing survey respondents to choose only one cognitive definition of homosexuality is inadequate for people who believe that homosexuality can mean multiple things, and it likely encourages many people to offer answers that they do not necessarily believe. Many people say that they do not have the knowledge to offer an opinion about what causes homosexuality, and asking them to do so proved to be a cognitively demanding and difficult task.

\section{References:}

1. Carter, David. (2004). Stonewoll: The Riot that Sparked the Gay Revolution. New York: St. Martin's Griffin. 
2. Cherlin, Andrew J. (2004). "The Deinstitutionalization of American Marriage". Journal of

3. Marriage and Family.

4. Johnson, David K. (2004). "The Lavander Scare: The 'Cold' War' Persecution of Gays and Lesbians in the Federal Government. Chicago: University of Chicago Press.

5. Lau, H. (2004). Sexual Orientation: Testing the Universality of International Human Rights Law. University of Chicago Law Review (Vol. 71).

6. Powell, Brian, Catherine Bolzendahl, Claudia Geist, and Lala Carr Steelman. (2010). Counted Out: Same-Sex Relations and Americans' Definitions of Family. New York: Russell Sage.

7. Rubin, Herbert J., and Irene S. Rubin. (2005). Qualitative Interviewing: The Art of Hearing Data. Thousand Oaks, CA: Sage Publications.

8. Stein, E. (1990). Forms of desire: sexual orientation and the social constructionist controversy. New York: Garland Publishing. 